University of Nebraska - Lincoln

DigitalCommons@University of Nebraska - Lincoln

$10-2005$

\title{
A Multi-Forest Comparison of Dietary Preferences and Seed Dispersal by Ateles spp.
}

\author{
Sabrina E. Russo \\ University of Nebraska - Lincoln, srusso2@unl.edu \\ Christina J. Campbell \\ Pomona College \\ J. Lawrence Dew \\ University of California - Berkeley \\ Pablo R. Stevenson \\ SUNY Stony Brook \\ Scott A. Suarez \\ SUNY Stony Brook
}

Follow this and additional works at: https://digitalcommons.unl.edu/bioscifacpub

Part of the Life Sciences Commons

Russo, Sabrina E.; Campbell, Christina J.; Dew, J. Lawrence; Stevenson, Pablo R.; and Suarez, Scott A., "A Multi-Forest Comparison of Dietary Preferences and Seed Dispersal by Ateles spp." (2005). Faculty Publications in the Biological Sciences. 231.

https://digitalcommons.unl.edu/bioscifacpub/231

This Article is brought to you for free and open access by the Papers in the Biological Sciences at DigitalCommons@University of Nebraska - Lincoln. It has been accepted for inclusion in Faculty Publications in the Biological Sciences by an authorized administrator of DigitalCommons@University of Nebraska - Lincoln. 
Published in the International Journal of Primatology (October 2005) 26(5): 1,017-1,037. DOI: 10.1007/s10764-005-6456-2. Copyright 2005, Springer. Used by permission.

\title{
A Multi-Forest Comparison of Dietary Preferences and Seed Dispersal by Ateles spp.
}

\author{
Sabrina E. Russo, ${ }^{1,5}$ Christina J. Campbell, ${ }^{2}$ J. Lawrence Dew, ${ }^{3}$ \\ Pablo R. Stevenson, ${ }^{4}$ and Scott A. Suarez ${ }^{4}$
}
${ }^{1}$ Department of Animal Biology, University of Illinois, Urbana, Illinois, U.S.A. ${ }^{2}$ Department of Anthropology, Pomona College, Claremont, California, U.S.A. ${ }^{3}$ Department of ESPM, University of California at Berkeley, Berkeley, California, U.S.A.
${ }^{4}$ Department of Anthropology, State University of New York at Stony Brook, Stony Brook, New York, U.S.A.
${ }^{5}$ To whom correspondence should be addressed. Affiliation 2012: School of Bio- logical Sciences, University of Nebraska-Lincoln, Lincoln, Nebraska, U.S.A.; srus- so2@unl.edu.

Article history: Received December 10, 2003; revision February 19, 2004; accepted March 24, 2004

Investigations of coevolutionary relationships between plants and the animals that disperse their seeds suggest that disperser-plant interactions are likely shaped by diffuse, rather than species-to-species, coevolution. We studied the role of dietary plasticity in shaping the potential for diffuse coevolution by comparing dietary fruit preferences and seed dispersal by 3 species of spider monkeys (Ateles spp.) in 4 moist forests in Colombia, Ecuador, Panama, and Surinam. In all forests, spider monkeys were highly frugivorous and preyed upon seeds of few species. We estimated dietary use of fruiting taxa based on absolute consumption and preference, which accounts for resource availability. Of the 59 genera that comprised the 20 most frequently consumed genera summed in each forest, only 3-Brosimum (Moraceae), Cecropia (Cecropiaceae) and Virola (Myristicaceae) - ranked within the top 20 at every forest. Most genera were within the 20 most frequently consumed at only 1 or 2 forests. Based on preferences, only 4 genera ranked in the 20 most-preferred in all 4 forests: Brosimum, Cecropia, Ficus (Moracae), and Virola. Patterns in fruit consumption and preference at the familial level were similar in that only 2 families - Myristicaceae and Moraceae-were in the 10 most-consumed or most-preferred in all 4 forests. Interforest variation in plant spe- 
cific composition and abundances and supra-annual fruiting phenologies, combined with dietary flexibility of Ateles spp., may partly explain these patterns. Our results suggest that variation in plant community structure strongly influences dietary preferences, and hence, seed dispersal by spider monkeys. Thus, diffuse coevolution in spider monkey-plant relationships may be limited to few taxa at the generic and familial levels.

Keywords: Ateles, Plant-disperser interactions, Coevolution, Frugivory, Seed dispersal.

\section{INTRODUCTION}

Investigating coevolutionary relationships between plants and the animals that disperse their seeds has been an important focus of seed dispersal biology, especially in tropical systems (Snow, 1971; McKey, 1975). Tiffney (1984), and Tiffney and Mazer (1995) linked increases in seed size of tree species and the diversification of large-seeded angiosperm species to the evolution of large-bodied frugivores that could disperse such large seeds. Likewise, Sussman (1991) proposed that increases in the availability of food resources displayed on terminal branches of angiosperms (fruits) led to the morphological adaptations of some primates to an arboreal life and contributed to primate diversification.

However, coevolution in terms of reciprocal evolutionary change among pairs of species, or pairwise coevolution (Janzen, 1980; Thompson, 1994; Futuyma, 1998), among partners in seed dispersal systems, has rarely been demonstrated (Wheelwright and Orians, 1982; Howe, 1984; Herrera, 1985). Weak selective pressures between dispersers and plants, spatial and temporal unpredictability of favorable germination sites for dispersed seeds, and long generation times of woody plants relative to their dispersers, all reduce the likelihood for tight, pairwise coevolutionary relationships to develop (Wheelwright and Orians, 1982; Howe, 1984; Herrera, 1985). In particular, plastic foraging ecologies of dispersers may prevent pairwise coevolution if composition and abundances of fruit resources in forests change rapidly in space and time, as empirical data suggest is often the case (Delcourt and Delcourt, 1987; Campbell, 1994; Colinvaux et al., 1996; Pitman et al., 2001; Condit et al., 2002).

Most evidence points toward disperser-plant relationships being shaped by diffuse, rather than pairwise, coevolution (Howe and Smallwood, 1982; Herrera, 1985). Diffuse coevolution occurs when either or both interacting populations are represented by an array of taxa that generate selective pressure as a group (Janzen, 1980; Thompson, 1994; Futuyma, 1998). In the case of seed dispersal, arrays of taxa involved in diffuse coevolution may be exemplified by groups of dispersal agents or fruiting 
plants at taxonomic levels above that of species. Evidence for diffuse coevolution comes from studies describing dispersal syndromes in plants, i.e., suites of plant traits, such as fruit color, size, and hardness, that may have evolved in a coordinated fashion in response to frugivory by broad classes of dispersal agents (van der Pijl, 1982). For example, in the Neotropics, fruits adapted for primate dispersal often may be large, yelloworange, brown, or green with a woody pericarp (Janson, 1983). However, African primates, tend to prefer red, in addition to yellow-orange, fruits and to avoid brown and green fruits (Gautier-Hion et al., 1985). These differences between New and Old World primates may be related to their dichromatic versus trichromatic vision, respectively (Surridge et al., 2003). Nonetheless, our understanding of the functional mechanisms behind primate-plant seed dispersal relationships is incomplete. Furthermore, data have been relatively unavailable to analyze variation in plant-disperser relationships across large spatial scales, an effort that is fundamental to understanding the role of dietary plasticity in shaping the potential for coevolution.

Primates in general (Chapman and Onderdonk, 1998) and spider monkeys (Ateles spp.) in particular (Andresen, 1999) are important frugivores and seed dispersers in tropical forests and therefore may have developed strong interactions with particular plant taxa. We assembled data on the role of spider monkeys as seed dispersers in moist forests in Colombia, Ecuador, Panama, and Surinam. We evaluated inter forest and inter year variation in their frugivory and seed predation to assess the potential for diffuse coevolutionary relationships between spider monkeys and the plants for which they disperse seeds.

\section{STUDY SITES AND SPECIES}

The 4 study sites (Table I) are moist forests, with varying degrees of seasonality ranging from the aseasonal forest at Yasuni, Ecuador, to the strongly seasonal forest on Barro Colorado Island (BCI), Panama. Two sites were relatively protected from human exploitation before and during the study periods. On BCI, spider monkeys were extirpated early in the 20th century and re-introduced in the 1960's (Milton, 1993). The spider monkey population at Yasuni has recently experienced moderate hunting pressure, losing ca. 10 females in a 2-year period (Suarez, 2003). Detailed descriptions of study sites were published by van Roosmalen (1985b) for Voltzberg, Stevenson (2002) for Tinigua, DiFiore and Rodman (2001) for Yasuni, and Leigh (1999) for Barro Colorado Island (BCI).

The different Ateles spp. have similar diets, social organization, and behavior, making them suitable for interspecific comparisons of diet in the context of understanding diffuse coevolution. Spider monkeys are large 


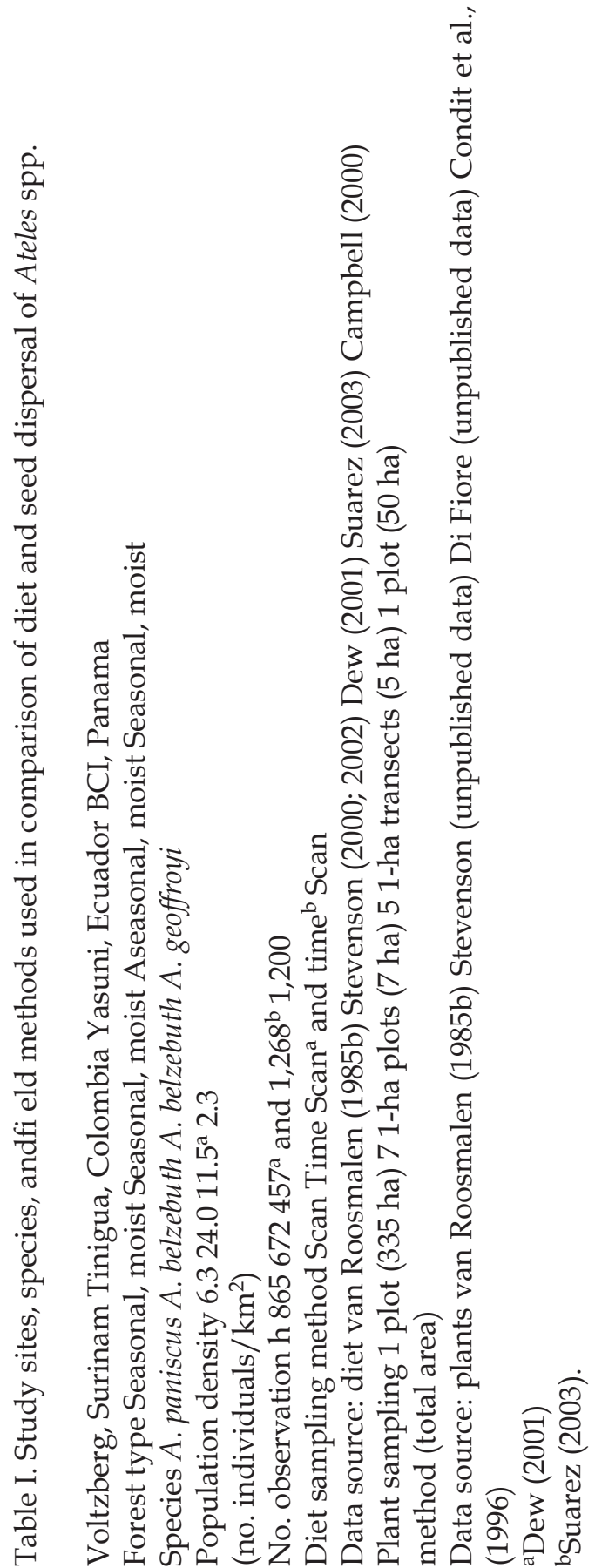


(5-8 kg) arboreal primates that primarily occupy the canopy strata of neotropical forests (Hershkovitz, 1978). Groups usually consist of 25-40 individuals and are organized in a fission-fusion social structure (Hershkovitz, 1978; McFarland, 1986). Spider monkeys are highly frugivorous, but also eat leaves, flowers, and occasionally insects in quantities that vary seasonally (Klein and Klein, 1977; Chapman, 1987; Symington, 1987).

\section{METHODS}

We gathered data on feeding ecology of spider monkeys and the abundances of fruiting tree species each site for 12 mo (Table I). Details of the field sampling methodologies are in the data source publications cited in Table I. We estimated absolute consumption of fruiting taxa at each site as either the percent of time (Tinigua and Yasuni) or scans (all other sites) spent by all focal individuals feeding on each species, summed at the generic and familial levels (hereafter, percent feeding). We estimated the abundances of fruit-producing species in spider monkey diets at each site based on tree census plots (Table I). Census plots varied in total area sampled and sampling method (Table I), making it inappropriate to make detailed quantitative comparisons among sites of the abundance of fruit resources consumed by spider monkeys. Therefore, we based estimates of similarity among sites in fruit resources on presence/absence and on ranks of abundances for taxa at multiple sites.

Data on fruit production was not available for all sites. Therefore, we estimated the availability at each site of species producing fleshy fruits consumed by spider monkeys as the percent of the total number of stems $(>10$ $\mathrm{cm}$ diameter at breast height) of the species in the site's census plot. Then we summed the percentages at the generic and familial levels (hereafter, percent availability).

We estimated dietary use of fruiting taxa based on both absolute consumption (percent feeding) and preference. Preference is based on absolute consumption, but takes into account the availability of the fruit resource. We calculated the preference index for each fruiting taxon in the diet as the difference between absolute consumption and availability (percent feeding minus percent availability). We standardized preference indices within sites so that they ranged from -1 to 1 , where in -1 indicates strongest avoidance, 1 indicates strongest preference, and zero indicates no preference (consumed according to abundance; Krebs, 1999).

We did not calculate preference indices in 2 cases: (1) for liana species, because only trees were censused in plots and (2) when there was no availability estimate for tree taxa. In both cases, we coded preference indices for the taxa as missing data and excluded them from analyses. Dew (2001), identified fruiting taxa generically only so we estimated availability for 
each genus by summing availability for all species in the genus present at the study site. For all other data sets, we summed only species in each genus that were included in the diet to estimate availability for the genus. In all data sets, we estimated availability at the familial level by summing all genera consumed at a site in each family. Dew (2001) and Suarez (2003), identified Lauraceae species only to family so we excluded their data on Lauraceae from our analyses.

We consider seeds to have been preyed upon if they were ingested, but were either not defecated intact or masticated. We also recorded seed species that the monkeys dropped under the parent tree.

\section{RESULTS}

Spider monkeys were highly frugivorous in all 4 forests (Table II). They ingested fruits and seeds of a large number of species in each forest and preyed upon seeds of few species (Figure 1, Table II). On average, 3.2\% of feeding observations involved seed predation (range 1.1-6.5\%).

Substantial congruence existed among the 4 forests in terms of the presence of tree genera producing fleshy fruits that were important in spider monkey diets. Across all forests, 59 genera comprised the 20 fruit-producing tree genera most frequently consumed by spider monkeys. Among pairs of forests, $54-80 \%$ of the 59 genera occurred in both forests in each pair (Table III). In terms of taxonomic composition, the least similar forests were Tinigua and Voltzberg, and the most similar forests were BCI and Yasuni (Table III). However, ranks of the abundance of fruit-producing genera are only significantly correlated between Voltzberg and Tinigua

Table II. Summary of the diets of 3 Ateles spp. from 4 neotropical forests

\begin{tabular}{|c|c|c|c|c|c|}
\hline & $\begin{array}{l}\text { Voltzberg, } \\
\text { Surinam }\end{array}$ & $\begin{array}{l}\text { Tinigua, } \\
\text { Colombia }\end{array}$ & $\begin{array}{l}\text { Yasuni, } \\
\text { Ecuador }^{\mathrm{a}}\end{array}$ & $\begin{array}{l}\text { Yasuni, } \\
\text { Ecuador }^{b}\end{array}$ & $\begin{array}{l}\text { BCI, } \\
\text { Panama }\end{array}$ \\
\hline Species & A paniscus & A belzebuth & A belzebuth & A belzebuth & A geoffroyt \\
\hline Fruit (\%) & 82.9 & 74.0 & 87.0 & 78.8 & 82.2 \\
\hline Leaves (\%) & 6.4 & 12.0 & 9.0 & 7.7 & 17.2 \\
\hline Flowers (\%) & 7.9 & 5.0 & 1.0 & 1.3 & 1.0 \\
\hline Other $(\%)$ & 2.7 & 9.0 & 0.7 & 12.2 & 0.6 \\
\hline Unidentified (\%) & 0 & 0 & 3.0 & 0 & 0.3 \\
\hline $\begin{array}{l}\text { No. fruit spp. } \\
\text { eaten }\end{array}$ & 160 & 106 & 71 & 238 & 107 \\
\hline $\begin{array}{l}\text { Seed predation } \\
\text { (\% species) }\end{array}$ & 6.5 & 2.0 & 2.8 & 0.8 & 1.0 \\
\hline
\end{tabular}



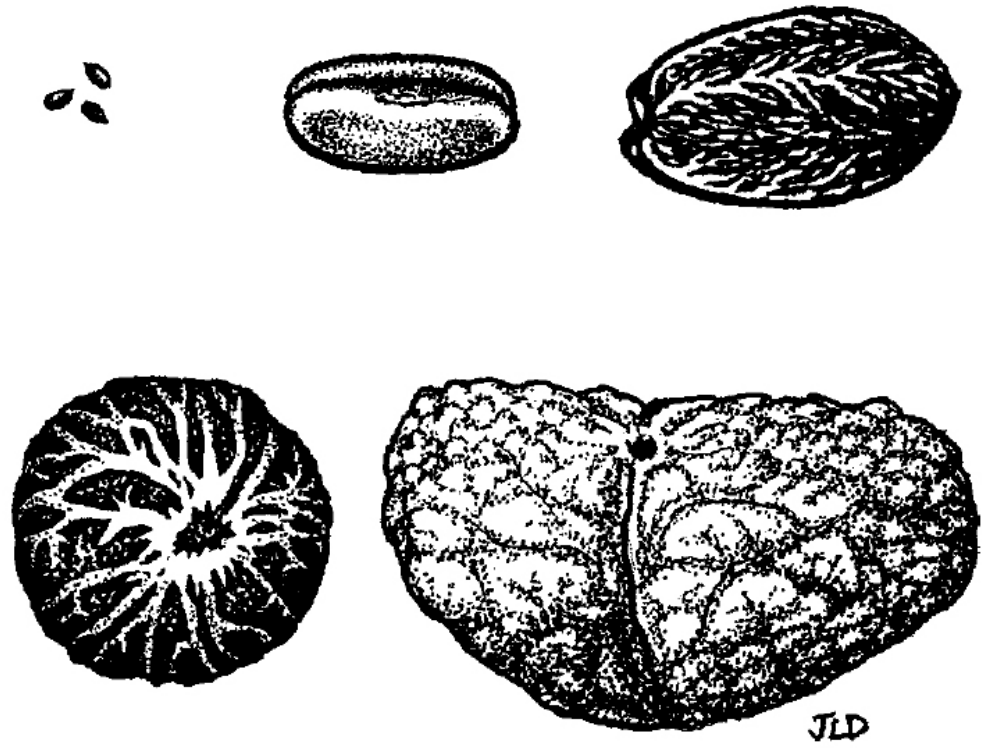

Figure 1. Seeds of trees dispersed by spider monkeys. Top row; left to right: Cecropia; Inga; Spondias, Bottom row; left to right: Iriartea; Iryanthera. Segments in scale bar correspond to $1 \mathrm{~cm}$. Illustration by J.L. Dew.

(Table IV). Hence, although they were dissimilar in terms of taxonomic composition (Table III), the abundances of the genera that occurred in both forests were congruent. Conversely, although BCI and Yasuni were most similar in terms of composition (Table III), the abundances of the genera present at both sites were not similar (Table IV).

Despite similarity among the 4 forests in the genera frequently consumed by spider monkeys, their diets were plastic. Few genera were

Table III. Percent of 59 genera producing fleshy fruits comprising the 20 most-consumed by spider monkeys that were present at both forests in each pair

Tinigua

Yasuni

Barro Colorado Island

$$
\begin{array}{ll}
\text { Voltzberg Tinigua } \\
54
\end{array}
$$$$
59
$$

56
78

71
Yasuni 
Table IV. Spearman rank correlation coefficients (probability, sample size) for the association between abundances of fruit-producing genera consumed by spider monkeys in forest pairs. The correlation between Voltzberg and Tinigua remained significant after correcting for multiple comparisons using the Bonferroni method (Sokal and Rohlf, 1995).

$\begin{array}{llll} & \text { Voltzberg } & \text { Tinigua } & \text { Yasuni } \\ \text { Tinigua } & 0.53(p<0.01, N=26) & & \\ \text { Yasuni } & -0.05(p=0.81, N=31) & 0.29(p=0.12, N=33) & \\ \text { Barro } & 0.32(p=0.21, N=17) & 0.39(p=0.12, N=17) & -0.12(p=0.77, N=20)\end{array}$

Colorado Island

important in their diets in multiple forests, either in terms of absolute consumption or in terms of preference, i.e., after accounting for the availability of the fruit resource (Figure 2A, B). Based on absolute consumption, of the 59 genera that comprised the 20 most-consumed genera from each forest, only 3 ranked in the top 20 in all 4 forests: Brosimum, Cecropia, and
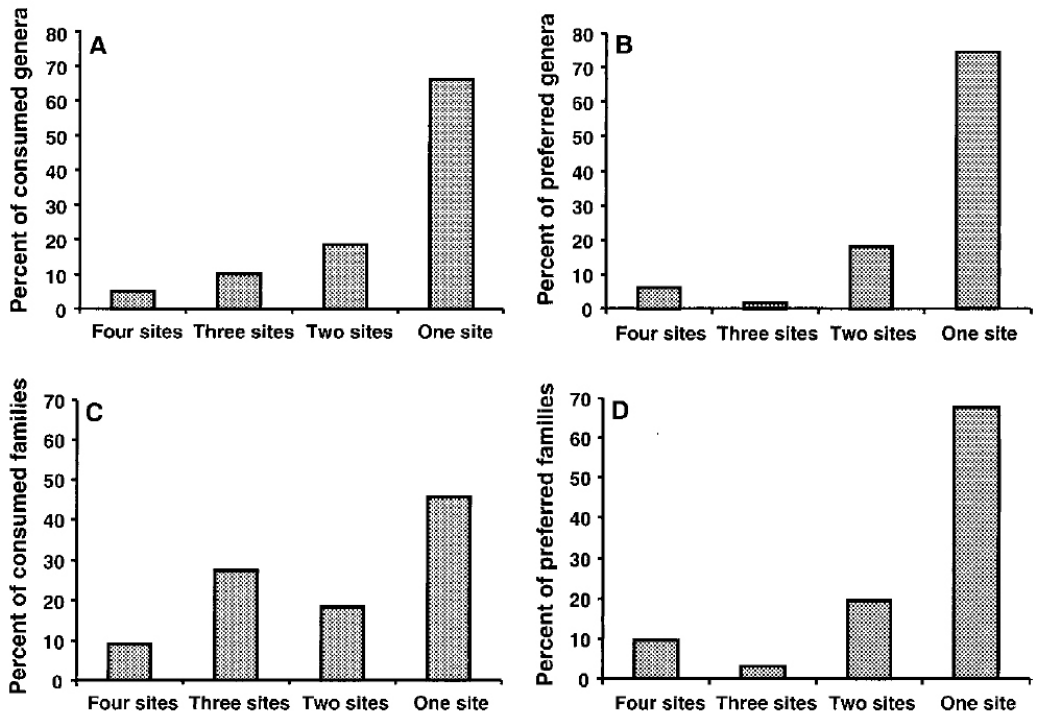

Figure 2. Percents of fruit-producing genera (A and B) or families (C and D) that were important in spider monkey diets in 4 neotropical forests either in terms of absolute consumption (A and $\mathrm{C}$ ) or after the availability of the fruit resource was taken into account (B and D). (A) Percent of 20 most-consumed genera summed over all forests (59 genera) that ranked in the top 20 genera in 4, 3, 2, and 1 forest. (B) Percent of 20 most-preferred genera summed over all forests (56 genera) that ranked in the top 20 genera in 4, 3, 2, and 1 forest. (C) Percent of the 10 most-consumed families summed over all forests (20 families) that ranked in the top $10 \mathrm{fam}$ ilies in 4, 3, 2, and 1 forest. (D) Percent of the 10 most-preferred families summed over all forests (27 families) that ranked in the top 10 families in 4, 3, 2, and 1 forest. 
Table V. The 10 most-consumed genera and families, numbers of species, and percent feeding by spider monkeys in four neotropical forests

\begin{tabular}{|c|c|c|c|c|c|}
\hline Genus & $\begin{array}{l}\text { No. species } \\
\text { eaten }\end{array}$ & $\begin{array}{l}\text { Percent } \\
\text { feeding }\end{array}$ & Family & $\begin{array}{l}\text { No. species } \\
\text { eaten }\end{array}$ & $\begin{array}{l}\text { Percent } \\
\text { feeding }\end{array}$ \\
\hline \multicolumn{6}{|l|}{ Voltzberg, Surinam } \\
\hline Virola (Myristicaceae) & 2 & 12.5 & Fabaceae & 21 & 15.2 \\
\hline Inga (Fabaceae) & 12 & 10.8 & Myristicaceae & 2 & 12.5 \\
\hline Guarea (Meliaceae) & 2 & 4.9 & Sapotaceae & 7 & 9.7 \\
\hline Tetragastris (Burseraceae) & 2 & 4.2 & Moraceae & 19 & 7.9 \\
\hline Ecclinusa (Sapotaceae) & 1 & 3.8 & Meliaceae & 6 & 6.7 \\
\hline Cecropia (Cecropiaceae) & 2 & 3.7 & Burseraceae & 4 & 6.3 \\
\hline Dimorphandra (Fabaceae) & 1 & 3.6 & Cecropiaceae & 8 & 5.4 \\
\hline Philodendron (Araceae) & 2 & 3.2 & Annonaceae & 5 & 4.0 \\
\hline Bagassa (Moraceae) & 1 & 3.2 & Araceae & 4 & 3.4 \\
\hline Achrouteria (Sapotaceae) & 1 & 3.0 & Flacourtiaceae & 1 & 2.5 \\
\hline \multicolumn{6}{|l|}{ Tinigua, Colombia } \\
\hline Ficus (Moraceae) & 8 & 15.4 & Moraceae & 21 & 25.5 \\
\hline Oenocarpus (Arecaceae) & 2 & 9.6 & Arecaceae & 7 & 14.0 \\
\hline Virola (Myristicaceae) & 3 & 7.3 & Cecropiaceae & 8 & 10.0 \\
\hline Gustavia (Lecythidaceae) & 1 & 6.9 & Burseraceae & 7 & 9.1 \\
\hline Protium (Burseraceae) & 4 & 5.8 & Myristicaceae & 5 & 7.5 \\
\hline Sarcaulus (Sapotaceae) & 1 & 5.5 & Lecythidaceae & 1 & 6.9 \\
\hline Brosimum (Moraceae) & 5 & 5.2 & Sapotaceae & 7 & 6.5 \\
\hline Pourouma (Cecropiaceae) & 4 & 4.0 & Fabaceae & 8 & 3.0 \\
\hline Pseudolmedia (Moraceae) & 3 & 3.8 & Anacardiaceae & 3 & 2.7 \\
\hline Cecropia (Cecropiaceae) & 2 & 3.5 & Meliaceae & 2 & 2.2 \\
\hline \multicolumn{6}{|l|}{ Yasuni, Ecuador ${ }^{\mathrm{a}}$} \\
\hline Spondias (Anacardiaceae) & - & 21.5 & Anacardiaceae & - & 21.5 \\
\hline Virola (Myristicaceae) & - & 14.6 & Myristicaceae & - & 18.7 \\
\hline Iriartea (Arecaceae) & - & 9.0 & Arecaceae & - & 14.0 \\
\hline Persea (Lauraceae) & - & 8.8 & Lauraceae & - & 8.9 \\
\hline Matisia (Bombacaceae) & - & 7.7 & Bombacaceae & - & 8.0 \\
\hline Guarea (Meliaceae) & - & 6.3 & Meliaceae & - & 6.9 \\
\hline Oenocarpus (Arecaceae) & - & 4.9 & Cecropiaceae & - & 6.2 \\
\hline Cecropia (Cecropiaceae) & - & 4.2 & Moraceae & - & 4.0 \\
\hline Iryanthera (Myristicaceae) & - & 4.2 & Fabaceae & - & 2.4 \\
\hline Naucleopsis (Moraceae) & - & 2.7 & Sapindaceae & - & 1.5 \\
\hline \multicolumn{6}{|l|}{ Yasuni, Ecuador ${ }^{b}$} \\
\hline Virola (Myristicaceae) & 8 & 12.3 & Moraceae & 22 & 19.0 \\
\hline Coccoloba (Polygonaceae) & 3 & 9.0 & Myristicaceae & 10 & 15.8 \\
\hline Pseudolmedia (Moraceae) & 4 & 5.3 & Polygonaceae & 4 & 9.0 \\
\hline Hyeronima (Euphorbiaceae) & 1 & 5.1 & Euphorbiaceae & 3 & 5.2 \\
\hline Brosimum (Moraceae) & 3 & 4.4 & Anacardiaceae & 2 & 4.3 \\
\hline Naucleopsis (Moraceae) & 2 & 4.4 & Bombacaceae & 3 & 4.2 \\
\hline Matisia (Bombacaceae) & 3 & 4.2 & Ulmaceae & 2 & 3.7 \\
\hline Ampelocera (Ulmaceae) & 1 & 3.7 & Fabaceae & 12 & 3.4 \\
\hline Iryanthera (Myristicaceae) & 1 & 3.5 & Arecaceae & 5 & 3.3 \\
\hline Tapira (Anacardiaceae) & 1 & 3.4 & Malphigiaceae & 1 & 3.3 \\
\hline \multicolumn{6}{|c|}{ Barro Colorado Island, Panama } \\
\hline Quararibea (Bombacaceae) & 1 & 12.4 & Bombacaceae & 1 & 12.4 \\
\hline Spondias (Anacardiaceae) & 2 & 10.3 & Moraceae & 9 & 9.2 \\
\hline Virola (Myristicaceae) & 1 & 8.5 & Anacardiaceae & 3 & 10.4 \\
\hline Hyeronima (Euphorbiaceae) & 1 & 6.6 & Myristicaceae & 1 & 8.5 \\
\hline Doliocarpus (Dillenaceae) & 2 & 5.6 & Euphorbiaceae & 3 & 7.3 \\
\hline
\end{tabular}


Table V. Continued

$\begin{array}{llllll} & \text { No. species } & \text { Percent } & & \text { No. species } & \begin{array}{l}\text { Percent } \\ \text { feeding }\end{array} \\ \text { Ficus (Moraceae) } & \text { eaten } & \text { feeding } & \text { Family } & \text { eaten } & 6.6 \\ \text { Astrocaryum (Arecaceae) } & 1 & 4.8 & \text { Arecaceae } & 3 & 6.1 \\ \text { Brosimum (Moraceae) } & 1 & 4.6 & \text { Rubiaceae } & 6 & 5.6 \\ \text { Chrysophyllum (Sapotaceae) } & 2 & 4.3 & \text { Dillenaceae } & 2 & 5.3 \\ \text { Tetragastris (Burseraceae) } & 1 & 4.1 & \text { Burseraceae } & 3 & 4.6\end{array}$

${ }^{a}$ Dew (2001).

bSuarez (2003).

Virola (Figure 2A and Table V). After adjusting absolute consumption to account for fruit availability, 4 genera ranked in the 20 most-preferred genera in all 4 forests: Brosimum, Cecropia, Ficus, and Virola (Figure 2B).The number of species in each genus varied somewhat among sites, ranging from only 1 species of Brosimum on BCI to 10 species of Virola and 10 species of Ficus at Yasuni and Voltzberg, respectively (Table VI).

As with genera, few families were important in spider monkey diets in multiple forests in terms of either absolute consumption or preference (Figure 2C, D). Based on absolute consumption, of the 20 families comprising the 10 most-consumed families from each forest, only 2-Moraceae and Myristicaceae (Figure 2C and Table V) - ranked in the top $10 \mathrm{in} \mathrm{ev-}$ ery forest. After adjusting absolute consumption to account for fruit availability, the same 2 families ranked in the 10 most-preferred families in every forest: Moraceae, and Myristicaceae (Figure 2D and Table V). Few genera ranked in the 20 most-consumed or in the 20 most-preferred in 2 or 3 forests (Figure 2A, B). However, at the familial level, a relatively greater proportion ranked within the 10 most-consumed families in 2 or 3 forests (Figure 2C). Thus, which genera or families were important in spider monkey diets tended to be forest-specific (Figure 2).

The importance of fruiting taxa in spider monkey diets may vary across forests due to differences in tree specific composition and abundance among them. Thirty-nine of the 59 genera comprising the 20 most-consumed gen-

Table VI. Numbers of species in 4 genera that were important in spider monkey diets in 4 neotropical forests as ranked within the 20 most-preferred genera in all 4 forests

\begin{tabular}{lllll} 
& \multicolumn{2}{l}{ Barro Colorado } & & \\
& Island & Voltzberg & Tinigua & Yasuni \\
Brosimum & 1 & 2 & 6 & 4 \\
Cecropia & 2 & 2 & 2 & 2 \\
Ficus & 8 & 10 & 8 & 5 \\
Virola & 2 & 2 & 3 & 10
\end{tabular}




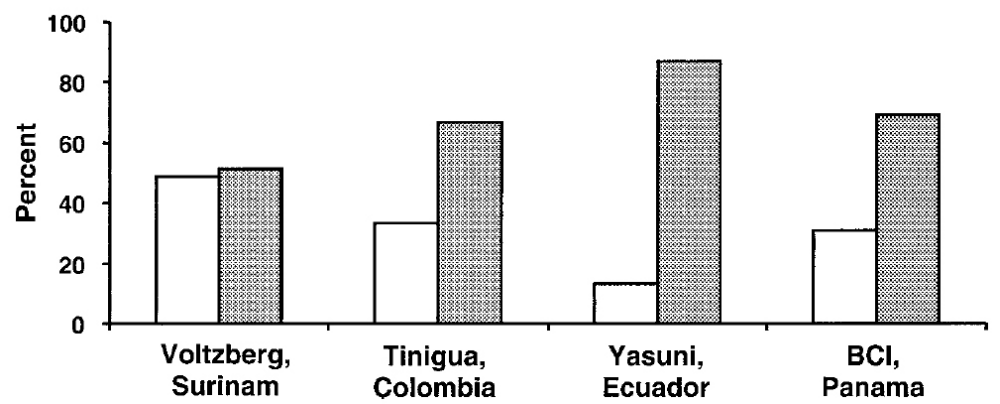

Figure 3. Percent of fruit-producing genera that did not rank in the 20 most-consumed by spider monkeys in a forest and were either absent (open) or present (gray fill) at each forest. Details in text.

era did not rank in the top 20 in a particular forest. Of those genera, an average of $31 \%$ did not occur in that forest, and variation among forests in this quantity is related to variation in their floras (Figure 3). Conversely, an average of $69 \%$ of the 39 genera were nonetheless present there (Figure 3). Furthermore, preference indices for a genus are only weakly correlated between forests (Table VII). Only for BCI and Yasuni, the 2 most floristically similar forests in terms of tree genera producing fleshy fruits (Table III) is the preference index of each genus correlated (Table VII). Conversely, the 2 forests with greatest similarity in abundances of fruit-producing genera - Voltzberg and Tinigua, (Table IV) - did not have a significant correlation in preference indices (Table VII).

Spider monkeys did not exhibit an overall tendency for strong preference for or avoidance of fruiting genera in their diets in each forest. The mean preference index in each forest is near zero, suggesting that, on average, genera are consumed according to their availability (Figure 4A).

Table VII. Spearman rank correlation coefficients (probability, sample size) for the association between spider monkey feeding preferences (preference indices) for each genus in forest pairs. We calculated preferences for Yasuni per both Dew (2001) and Suarez (2003) by averaging the preference index for a genus when it was consumed in both studies, or, for genera only consumed in one study, by using the preference index from that study. The correlation between Yasuni and Barro Colorado Island remained significant after correcting for multiple comparisons using the Bonferroni method (Sokal and Rohlf, 1995).

$\begin{array}{lllc} & \text { Voltzberg } & \text { Tinigua } & \text { Yasuni } \\ \text { Tinigua } & 0.28(p=0.17, N=26) & & \\ \text { Yasuni } & 0.13(p=0.48, N=31) & 0.27(p=0.13, N=33) & \\ \text { Barro Colorado } & 0.34(p=0.18, N=17) & 0.25(p=0.33, N=17) & 0.63(p<0.01, \\ \text { Island } & & & N=20)\end{array}$




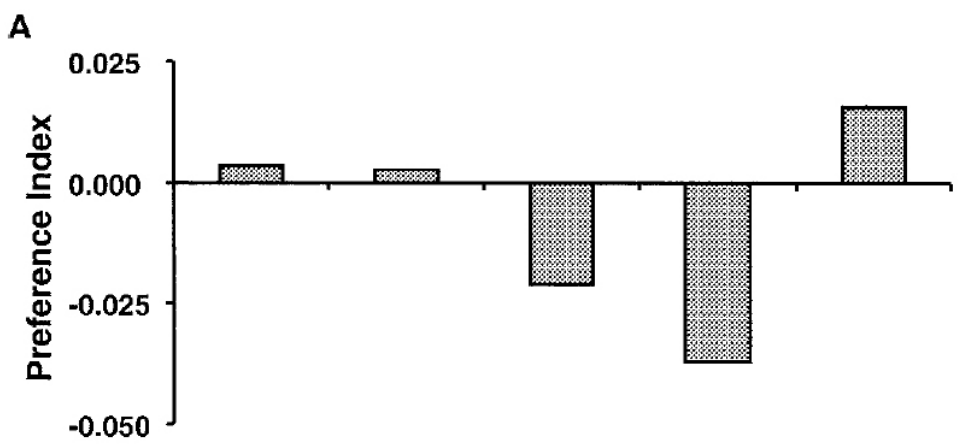

B

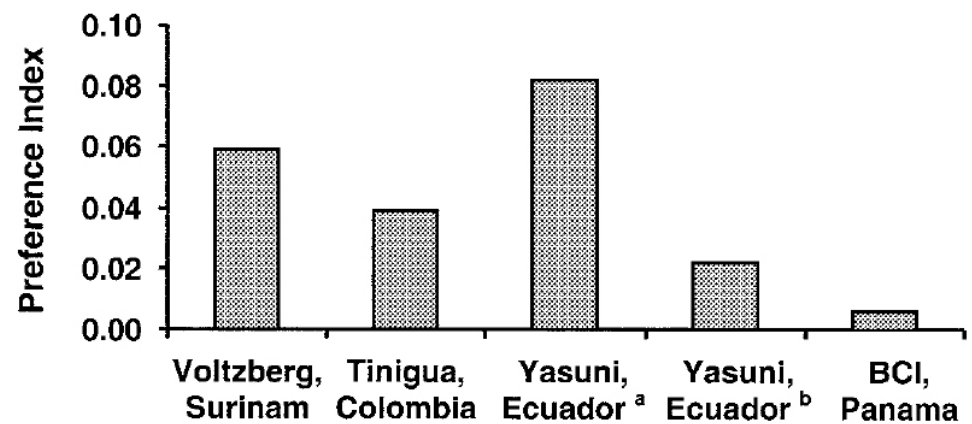

Figure 4. Mean (A) and variance (B) of preferences indices for all genera consumed by spider monkeys at each forest. The 2 studies at Yasuni, Ecuador, are in separate sets of bars; a refers to Dew (2001), and b refers to Suarez (2003).

Instead, variation in preference indices is high, indicating that a few taxa are strongly preferred and a few others strongly avoided (Figure 4B). Genera that ranked within the 20 most-preferred in $=2$ forests are Astrocaryum (Arecaceae), Brosimum (Moraceae), Cecropia (Cecropiaceae), Coccoloba (Polygonaceae), Ficus (Moraceae), Guatteria (Annonaceae), Hyeronima (Euphorbiaceae), Spondias (Anacardiaceae), and Virola (Myristicaceae). Genera that the monkeys avoided include ones with high population densities in individual forests, such as Guarea (Meliaceae), Iriartea (Arecaceae), Mouriri (Melastomataceae), Protium (Burseraceae), Pseudolmedia (Moraceae), Tetragastris (Burseraceae), and Trichilia (Meliaceae). The mean preference index is highest and variance lowest on BCI.

Dietary patterns of spider monkeys indicate their roles as seed dispersers because seeds of few species were preyed upon (Table II) or dropped below the parent tree (Table VIII). Among forests, there are some similarities as to which tree species seeds were preyed upon (Table VIII). Spider 
Table VIII. Seeds experiencing predation by spider monkeys in 4 neotropical forests. Unless otherwise noted by abbreviations following species names, seeds were either digested or unripe fruits were eaten. Abbreviations: $\mathrm{m}$, seed masticated; $\mathrm{d}$, seed dropped under parent

\begin{tabular}{|c|c|}
\hline Species & Family \\
\hline \multicolumn{2}{|l|}{ Voltzberg, Surinam } \\
\hline Tanaecium nocturnum & Bignoneaceae \\
\hline Anomoctenium granulosum & Bignoneaceae \\
\hline Pachira insignis & Bombacaceae \\
\hline Cheiloclinium cognatum & Celastraceae \\
\hline Combretum rotundifolium & Combretaceae \\
\hline Maripa glabra & Convolvulaceae \\
\hline Maripa scandens & Convolvulaceae \\
\hline Operculina hamiltoni & Convolvulaceae \\
\hline Alchorneopsis floribunda & Euphorbeaceae \\
\hline Couratari spp. & Lecythidaceae \\
\hline Eschweilera spp. & Lecythidaceae \\
\hline Eperua spp. & Fabaceae \\
\hline Cedrelinga cateniformis & Fabaceae \\
\hline Dioclea macrocarpa & Fabaceae \\
\hline Ormosia paraensis & Fabaceae \\
\hline Carapa procera & Meliaceae \\
\hline Cedrela odorata & Meliaceae \\
\hline Paullinia sphaerocarpa & Sapindaceae \\
\hline Prieurella sp. & Sapotaceae \\
\hline Pouteria sp & Sapotaceae \\
\hline \multicolumn{2}{|l|}{ Tinigua, Colombia } \\
\hline Astrocaryum chambira (m) & Arecaceae \\
\hline Brosimum spp. & Moraceae \\
\hline Oenocarpus bataua & Arecaceae \\
\hline Pseudolmedia spp. & Moraceae \\
\hline \multicolumn{2}{|l|}{ Yasuni, Ecuador ${ }^{\mathrm{a}, \mathrm{b}}$} \\
\hline Astrocaryum chambira & Arecaceae \\
\hline Iriartea deltoidea & Arecaceae \\
\hline \multicolumn{2}{|l|}{ Barro Colorado Island, Panama } \\
\hline Astrocaryum standleyanum (d) & Arecaceae \\
\hline Beilschmedia pendula (d) & Lauraceae \\
\hline Brosimum alicastrum & Moraceae \\
\hline Dipteryx panamensis $(\mathrm{d})$ & Leguminosae \\
\hline
\end{tabular}


monkeys preyed upon seeds of Brosimum and palm species in 2 and 3 forests, respectively (BCI and Tinigua, and BCI, Yasuni, and Tinigua, respectively). Most seed predation involved consumption of unripe fruit. They dropped seeds of very large-seeded species below the parent, and therefore did not disperse them, e.g., Dipteryx, Beilschmedia.

Data from Yasuni collected in 2 study years allowed an evaluation of the interaction between temporal variation in fruit availability and spider monkey diets. There is a significant correlation between the preference indices of genera consumed in both studies (Spearman $r=0.64, p=$ 0.001); however, there is considerable variation in the relationship. Of the 31 genera comprising the 20 most-consumed genera in the 2 studies at Yasuni, only $30 \%$ ranked in the top 20 in both. Hence, spider monkey diets, as measured by the most frequently consumed fruiting species, varied substantially on an annual basis in the same forest, even when comparing only 2 years. In at least 2 cases - Brosimum lactescens and Spondias mombin -variation in preference was due to low fruit production in one study year and high production in the other (S.A. Suarez and J.L. Dew, personal observations).

\section{DISCUSSION}

Spider monkey diets varied across forests and years in terms of both absolute consumption and preference, which is consistent with results of other comparative studies of primates (Chapman and Chapman, 2002b). Our results suggest that variation in composition and abundance of fruiting taxa among forests and years strongly influences foraging choices, and hence seed dispersal by spider monkeys. Spider monkeys tended to consume most taxa according to their availability, as has been observed in at least one other study (Nunes, 1998). Nonetheless, they strongly preferred some genera, and avoided others. Strong interactions between spider monkeys and fruiting taxa that were consistent across all forests are limited to few genera-Brosimum, Cecropia, Ficus, and Virola-and families: Moraceae and Myristicaceae. From the plant's perspective, such dietary plasticity means that the selective pressures of spider monkeys on plant and fruit traits affecting dispersal are not consistent in space, even among forests with broad floristic similarity. Thus, diffuse coevolution in spider monkey-plant relationships may be limited to few taxa at the generic and familial levels.

Coevolution between a plant and a particular dispersal agent depends on spatial and temporal consistency in their interaction, as well as the interactions the plant has with other species that may also be important dispersers (Herrera, 2002). Hence, it is important to consider whether the 4 genera with which spider monkeys appear to have consistent interactions 
are substantially dispersed by other dispersal agents. Cecropia and Ficus spp. are well-known to be consumed (and likely dispersed) by many frugivores (Tello, 2003; Fleming and Williams, 1990). They fit the paradigmatic generalist dispersal syndrome in having sugar-rich, small-seeded fruits and being prodigious fruit-producers (McKey, 1975). Brosimum spp. also attract a diversity of frugivores (S.E. Russo, personal observation). However, seeds of Brosimum are larger than those of Cecropia and Ficus (van Roosmalen, 1985a), which inevitably excludes smaller dispersal agents. In addition, spider monkeys preyed upon seeds of Brosimum in at least 2 forests. The relative proportions of ingested seeds that were dispersed versus preyed upon is unknown, but would likely be an important influence on the fruit traits of at Brosimum experiencing selection by spider monkeys, as well as the nature of that selection.

Conversely, Virola spp. appear to be dispersed by a relatively narrower assemblage of species (Howe, 1981; Howe and Vande Kerckhove, 1981; Russo, 2003), perhaps in part because of the generally larger seed sizes and the oily, rather than sugary, aril characteristic of the genus (van Roosmalen, 1985a). Hence, we predict that of the 4 genera, Virola would experience the strongest selection on tree and fruit traits as a result of seed dispersal by spider monkeys. However, a detailed analysis of this possibility in Virola calophylla in Perú showed that divergent selection from even a limited assemblage of other dispersal agents may counter any selection from spider monkeys (Russo, 2003). Thus, further research is necessary to understand responses to selection, but it appears that even consistent, strong interactions between dispersal agents and fruit-producing tree species may not be sufficient for dispersers to shape the traits of the plants they disperse.

Variation in spider monkey dietary consumption and preferences for fruiting taxa among forests may be explained by extrinsic and intrinsic factors. First, variation in both the composition and abundance of fruiting taxa is likely a strong influence on spider monkey foraging decisions. Three results support this conclusion. First, the 2 forests that shared the greatest number of genera most-frequently consumed by spider monkeys (BCI and Yasuni) showed the greatest correlation in preference indices, which suggests that taxonomic composition of fruiting taxa in a forest plays an important role in spider monkey foraging choices. Second, we also found that of the 39 genera comprising the 20 most-consumed genera that were not ranked in the top 20 in a particular forest, most were nonetheless still present in that forest, which suggests that a substantial amount of the variation among forests in spider monkey diets is due to foraging choices among fruiting taxa present and their abundances, rather than the absence of fruiting taxa. Furthermore, the fact that the preference indices for a genus were only weakly correlated between forests is 
consistent with this interpretation. Third, the 2 forests with the most correlated abundances of genera (Voltzberg and Tinigua) do not have significantly correlated preference indices. This result must be considered with caution because the tree abundance data were not designed for acrosssite comparisons. However, we can tentatively conclude that abundances of fruiting genera alone do not determine spider monkey foraging decisions. Taken together, our analyses suggest that both taxonomic composition and abundances of fruiting taxa in forests strongly influence spider monkey foraging choices and, hence, seed dispersal.

Second, interspecific variation in feeding among species of Ateles may explain variation among forests in fruit consumption and preferences. If this were the case, then forests with the same species of Ateles should have the greatest correlation between preference indices, all else being equal. However, the correlation in preference indices between forests is not highest for Tinigua and Yasuni, the only forests that share the same species of Ateles. Given that current taxonomy reflects phylogeny, this result suggests that phylogeny may not be a dominant factor determining the patterns of variation in diet that we observed in Ateles.

Third, variation among forests in specific composition and interspecific interactions among sympatric frugivorous primates is also likely to influence spider monkey foraging choices. Studies of diets of frugivorous primates suggest that species partition fruit resources based on fruit characteristics (Kinzey and Norconk, 1990; Ungar, 1995; Dew, 2001). BCI, which has the lowest population density of spider monkeys and the fewest species of sympatric, frugivorous primates, had the highest mean preference index and lowest variance. In addition, the single group on $\mathrm{BCI}$ has an extremely large home range (Campbell, 2000). A potential explanation for these patterns is that spider monkeys on BCI may be less constrained by intra-and interspecific competition in their foraging choices, and therefore may be freer to use preferred fruit resources.

Fourth, the comparison between 2 study years at Yasuni indicated the importance of accounting for supra-annual fruiting phenology and the availability of fruit resources in understanding foraging choices of spider monkeys. Similarly, at least 1 genus on BCI (Faramea) had a very low preference index in the single year of data collection there, when the population of Faramea produced little fruit. However, in other years when Faramea fruited prodigiously on BCI, spider monkeys foraged extensively on this genus (C.J. Campbell, personal observation). More sampling years in all forests would probably reveal a greater number of genera and families ranking as important dietary components in all forests. However, the fact that Brosimum, Cecropia, and Virola are important in all forests, even in one year of sampling, suggests that the spider monkeys have strong relationships with them. In particular, in all forests, Virola is within the top 3 
genera having the greatest consumption, followed by a large drop in consumption rates for lower-ranked genera (Table V). Virola is also important in the diets of spider monkeys in Manú National Park, Perú, where 92\% of dispersed seeds of Virola calophylla were dispersed by spider monkeys (Russo, 2003).

Finally, primate foraging choices are influenced by many factors, including caloric, nutrient, and secondary chemical contents of resources, the abundance, spatial distribution, and temporal predictability of resources, and competition (Clutton-brock, 1977; Hladik, 1977; Terborgh, 1983; van Schaik et al., 1993; Kaplin et al., 1998; Chapman and Chapman, 2002a). Several factors may contribute to consistent preferences by spider monkeys for Brosimum, Cecropia, Virola, and Ficus. Brosimum may be preferred because of the generally large quantities of fruit produced and long periods of fruit availability on individual trees. Cecropia may be preferred because of its extended fruiting phenology, as has been suggested in a comparative study of the diets of avian dispersal agents (Carlo et al., 2003). Similarly, Virola may be preferred for reliable annual fruit production. $\mathrm{Vi}$ rola had consistent fruit production every year for 4 years in Manú National Park, Perú (S.E. Russo, unpublished data) and for 10 years on BCI (S.J. Wright, personal communication). In contrast, 3 important genera in spider monkey diets-Brosimum, Clarisia, and Pseudolmedia-produced no fruit in at least 1 of the 4 years in Manú National Park (S.E. Russo, unpublished data). Ficus may be preferred because it often fruits in seasons of resource scarcity (Terborgh, 1986; Ahumada et al., 1998).

Our findings have important conservation implications. For plants, spider monkeys play a particularly vital role in dispersing a large number of tropical genera. Spider monkeys are one of the first animals to be hunted out of forests (Redford, 1992; Peres, 2000), and their loss is likely to have important consequences for demography, community structure, and gene flow of trees and lianas in tropical forests (Chapman and Chapman, 1995; Chapman and Onderdonk, 1998; Pacheco and Simonetti, 2000). For spider monkeys, dietary plasticity may enable them to vary foraging in response to loss of an important food resource, e.g., as a result of selective logging or changes in resource abundance as a result of climate change or mild disturbance (Chapman and Chapman, 1990).

Evaluating potential coevolutionary relationships among plants and their animal seed dispersers requires using a comparative approach that accounts for both the ecological patterns across multiple closely related species in a geographic context and the evolutionary trends in those patterns (Thompson, 1999). Our research constitutes one of the few comparative studies of diet and seed dispersal in primates across large geographic areas. Nonetheless, its limitations must be acknowledged. We collected feeding data for only one year in all but one forest, yet many neotropical 
fruiting species demonstrate supra-annual variation in fruit production, and diets of neotropical primates are flexible on both seasonal and annual bases (Chapman, 1987; Chapman et al., 2002). Methods of collection of feeding and tree abundance data varied among forests, which could confound interpretation of patterns (Stevenson and Quiñones, in press). Ideally, availability of fruits would be measured directly, rather than by way of the correlate of population density. We hope that future comparative data sets can be assembled to examine further which factors influence frugivory and seed dispersal by primates.

\section{ACKNOWLEDGMENTS}

Fieldwork on BCI by Campbell was supported by grants from the National Science Foundation (SBR-9711161), the L.S.B. Leakey Foundation, the Department of Anthropology, University of California, Berkeley, and the Smithsonian Tropical Research Institute. Campbell also thanks Antigone Thomas, Dr. S. Joseph Wright, and Osvaldo Calderon for help in collecting data. Dew thanks the National Science Foundation, the Douroucouli Foundation, Primate Conservation Incorporated, Tony Di Fiore, Kristin Phillips, and Peter Rodman. Stevenson thanks Jorge Ahumada and Marcela Quiñones, who helped in data collection, and Banco de la Republica, Centro de Investigaciones Ecologicas La Macarena, and Colciencias for their support. Suarez thanks the L.S.B. Leakey Foundation, the National Science Foundation, Dr. Peter Rodman for financial support, and Gorky Villa, Nigel Pitman, Jill Anderson, Jacob Nabe-Nielson, Robyn Burnham, and Robin Foster for botanical assistance. Russo was supported by a Dissertation Completion Fellowship from the University of Illinois while writing this article and thanks Carol K. Augspurger for constructive input. We also thank 2 anonymous reviewers for comments that improved an earlier version of this article.

\section{REFERENCES}

Ahumada, J.A., Stevenson, P.R., and Quiñones, M.J. (1998). Ecological response of spider monkeys to temporal variation in fruit abundance: the importance of flooded forest as a keystone habitat. Prim. Conserv. 18: 10-14.

Andresen, E. (1999). Seed dispersal by monkeys and the fate of dispersed seeds in a Peruvian rainforest. Biotropica 31: 145-158.

Campbell, C.J. (2000). The Reproductive Biology of Black-handed Spider Monkeys (Ateles geoffroyi): Integrating Behavior and Endocrinology. Ph.D. thesis, University of California, Berkeley.

Campbell, D.G. (1994). Scale and patterns of community structure in Amazonian forests. In: Edwards, P.J., May, R.M., and Webb, N.R. (eds.), Large-Scale Ecology and Conservation Biology. Blackwell Scientific, London, pp. 179-197.

Carlo, T.A., Collazo, J.A., and Groom, M.J. (2003). Avian fruit preferences across a Puerto Rican forested landscape: pattern consistency and implications for seed removal. Oecologia 134: 119-131.

Chapman, C. (1987). Flexibility in diets of three species of Costa Rican primates. Folia Primatol. 49: 90-105.

Chapman, C.A., and Chapman, L.J. (1990). Dietary variability in primate populations. Primates 31: 121-128. 
Chapman, C.A., and Chapman, L.J. (1995). Survival without dispersers: seedling recruitment under parents. Cons. Biol. 9: 675-678.

Chapman, C.A., and Chapman, L.J. (2002a). Foraging challenges of red colobus monkeys: influence of nutrients and secondary compounds. Comp. Biochem. Phys. A 133: 861-875.

Chapman, C.A., and Chapman, L.J. (2002b). Plant-animal coevolution: is it thwarted by spatial and temporal variation in animal foraging? In: Levey, D.J., Silva, W.R., and Galetti, M. (eds.), Seed Dispersal and Frugivory: Ecology, Evolution, and Conservation. CABI, New York, pp. 275-290.

Chapman, C.A., Chapman, L.J., and Gillespie, T.R. (2002). Scale issues in the study of primate foraging: red colobus of Kibale National Park. Am. J. Phys. Anthropol. 117: 349-363.

Chapman, C.A., and Onderdonk, D.A. (1998). Forests without primates: primate/ plant codependency. Am. J. Primatol. 45: 127-141.

Clutton-brock, T.H. (1977). Some aspects of intraspecific variation in feeding and ranging behavior in primates. In: Clutton-Brock, T.H. (ed.), Primate Ecology: Studies of Feeding and Ranging Behavior in Lemurs, Monkeys and Apes. Academic Press, London, pp. 539-556.

Colinvaux, P.A., De Oliveira, P.E., Moreno, J.E., Miller, M.C., and Bush, M.B. (1996). A long pollen record from lowland Amazonia: forest and cooling in glacial times. Science 275: 85-88.

Condit, R., Hubbell, S.P., and Foster, R.B. (1996). Changes in tree species abundance in a neotropical forest: impact of climate change. J. Trop. Ecol. 12: 231-256.

Condit, R., Pitman, N., Leigh, E.G., Chave, J., Terborgh, J., Foster, R.B., Nunez, V.P., et al. (2002). Beta-diversity in tropical forest trees. Science 295: 666-669.

Delcourt, P.A., and Delcourt, H.R. (1987). Long-Term Forest Dynamics in the Temperate Zone. Springer-Verlag, New York.

Dew, J.L. (2001). Synecology and Seed Dispersal in Woolly Monkeys (Lagothrix lagotricha poeppigii) and Spider Monkeys (Ateles belzebuth belzebuth) in Parque Nacional Yasuní, Ecuador. Ph.D. thesis, University of California, Davis.

Di Fiore, A., and Rodman, P.S. (2001). Time allocation patterns of lowland woolly monkeys (Lagothrix lagotricha poeppigii) in a Neotropical terra firma forest. Int. J. Primatol. 22: 449-480.

Fleming, T.H., and Williams, C.F. (1990). Phenology, seed dispersal, and recruitment in Cecropia peltata (Moraceae) in Costa Rican tropical dry forest. J. Trop. Ecol. 6: 163-178.

Futuyma, D.J. (1998). Evolutionary Biology. Sinauer Associates, Sunderland.

Gautier-Hion, A., Duplantier, J.M., Quris, R., Feer, F., Sourd, C., Decoux, J.-P., Dubost, G., et al. (1985). Fruit characters as a basis of fruit choice and seed dispersal in a tropical forest vertebrate community. Oecologia 65: 324-337.

Herrera, C.M. (1985). Determinants of plant-animal coevolution: The case of mutualistic dispersal of seeds by vertebrates. Oikos 44: 132-141.

Herrera, C.M. (2002). Seed dispersal by vertebrates. In: Herrera, C. M., and Pellmyr, O. (eds.), Plant-Animal Interactions: An Evolutionary Approach. Blackwell Science, Oxford., pp. 185-210.

Hershkovitz, P. (1978). Living New World Monkeys, Platyrrhini: With an Introduction to Primates. University of Chicago Press, Chicago.

Hladik, C.M. (1977). Chimpanzees of Gabon and chimpanzees of Gombe: some comparative data on the diet. In: Clutton-Brock, T.H. (ed.), Primate Ecology: Studies of Feeding and Ranging Behavior in Lemurs, Monkeys and Apes. Academic Press, London, pp. 481-501. 
Howe, H.F. (1981). Dispersal of a neotropical nutmeg (Virola sebifera) by birds. Auk 98: 88-98.

Howe, H.F. (1984). Constraints on the evolution of mutualisms. Am. Nat. 123: 764-777. Howe, H.F., and Smallwood, J. (1982). Ecology of seed dispersal. Ann. Rev. Ecol. Syst. 13: 201-228.

Howe, H.F., and Vande Kerckhove, G.A. (1981). Removal of wild nutmeg (Virola surinamensis) crops by birds. Ecology 62: 1,093-1,106.

Janson, C.H. (1983). Adaptation of fruit morphology to dispersal agents in a Neotropical forest. Science 219: 187-189.

Janzen, D.H. (1980). When is it coevolution? Evolution 34: 611-612.

Kaplin, B.A., Munyaligoga, V., and Moermond, T.C. (1998). The influence of temporal changes in fruit availability on diet composition and seed handling in blue monkeys (Cercopithecus mitis doggetti). Biotropica 30: 56-71.

Kinzey, W.G., and Norconk, M.A. (1990). Hardness as a basis of fruit choice in two sympatric primates. Am. J. Phys. Anthropol. 81: 5-15.

Klein, L.L., and Klein, D.J. (1977). Feeding behavior of the Colombian spider monkey, Ateles belzebuth. In: Clutton-Brock, T.H. (ed.), Primate Ecology: Studies of Feeding and Ranging Behavior in Lemurs, Monkeys, and Apes. Academic Press, New York, pp. 153-181.

Krebs, C.J.(1999).EcologicalMethodology.Benjamin/Cummings,MenloPark, California.

Leigh, E.G. (1999). Tropical Forest Ecology: A View from Barro Colorado Island. Oxford University Press, Oxford.

McFarland, M.J. (1986). Ecological determinants of fission-fusion sociality in Ateles and Pan. In: Else, J. G., and Lee, P.C. (eds.), Primate Ecology and Conservation. Cambridge University Press, Cambridge, pp. 181-190.

McKey, D. (1975). The ecology of coevolved seed dispersal systems. In: Gilbert, L. E., and Raven, P. H. (eds.), Coevolution of Animals and Plants. University of Texas Press, Austin, pp. 159-191.

Milton, K. (1993). Diet and social organization of a free-ranging spider monkey population: the development of species-typical behavior in the absence of adults. In: Pererira, M. E., and Fairbanks, L. A. (eds.), Juvenile Primates: Life History, Development, and Behavior. Oxford University Press, Oxford, pp. 136-144.

Nunes, A. (1998). Diet and feeding ecology of Ateles belzebuth belzebuth at Maraca Ecological Station, Roraima, Brazil. Folia Primatol. 69: 61-76.

Pacheco, L.F., and Simonetti, J.A. (2000). Genetic structure of a mimosoid tree deprived of its seed disperser, the spider monkey. Cons. Biol. 14: 1,766-1,775.

Peres, C.A. (2000). Effect of subsistence hunting on vertebrate community structure in Amazonian forests. Cons. Biol. 14: 240-253.

Pitman, N.C.A., Terborgh, J.W., Silman, M.R., Nunez, V.P., Neill, D.A., Ceron, C.E., Palacios, W.A., et al. (2001). Dominance and distribution of tree species in upper Amazonian terra firme forests. Ecology 82: 2,101-2,117.

Redford, K.H. (1992). The empty forest. Bioscience 42: 412-422.

Russo, S.E. (2003). Responses of dispersal agents to tree and fruit traits in Virola calophylla (Myristicaceae): implications for selection. Oecologia 136: 80-87.

Snow, D.W. (1971). Evolutionary aspects of fruit-eating by birds. Ibis 113: 194-202.

Sokal, R.R., and Rohlf, F.J. (1995). Biometry. W.H. Freeman, New York.

Stevenson, P.R. (2002). Frugivory and Seed Dispersal by Wooly Monkeys at Tinigua National Park, Colombia. Ph.D. thesis, State University of New York at Stony Brook, Stony Brook. 
Stevenson, P.R., and Quiñones, M.J. (2004). Sampling methods used to quantify activity patterns and diet: a comparative example using woolly monkeys (Lagothrix lagotricha). Field Studies of Fauna and Flora La Macarena Colombia 14: 21-28.

Stevenson, P.R., Quiñones, M.J., and Ahumada, J.A. (2000). Influence of fruit availability on ecological overlap among four neotropical primates at Tinigua National Park, Colombia. Biotropica 32: 533-544.

Suarez, S.A. (2003). Spatio-Temporal Foraging Skills of White-Bellied Spider Monkeys (Ateles belzebuth belzebuth) in the Yasuni National Park, Ecuador. Ph.D. thesis, State University of New York at Stony Brook, Stony Brook.

Surridge, A.K., Osorio, D., and Mundy, N.I. (2003). Evolution and selection of trichromatic vision in primates. TREE 18: 198-205.

Sussman, R.W. (1991). Primate origins and the evolution of angiosperms. Am. J. Primatol. 23: 209-223.

Symington, M.M. (1987). Demography, ranging patterns, and activity budgets of black spider monkeys (Ateles paniscus chamek) in the Manú National Park, Perú. Am. J. Primatol. 15: 45-67.

Tello, J.G. (2003). Frugivores at a fruiting Ficus in south-eastern Peru. J. Trop. Ecol. 19: 717-721.

Terborgh, J. (1983). Five New World Primates. Princeton University Press, Princeton, New Jersey.

Terborgh, J. (1986). Keystone plant resources in the tropical forest. In: Soulé, M. E. (ed.), Conservation Biology: The Science of Scarcity and Diversity. Sinauer Associates, Sunderland, pp. 330-344.

Thompson,J.N.(1994). The Coevolutionary Process. University of Chicago Press, Chicago.

Thompson, J.N. (1999). Specific hypotheses on the geographic mosaic of coevolution. Am. Nat. 153: S1-S14.

Tiffney, B.H. (1984). Seed size, dispersal syndromes, and the rise of the angiosperms: evidence and hypotheses. Ann. Mo. Bot. Gard. 71: 551-576.

Tiffney, B.H., and Mazer, S.J. (1995). Angiosperm growth habit, dispersal and diversification reconsidered. Evol. Ecol. 9: 93-117.

Ungar, P.S. (1995). Fruit preferences of four sympatric primates species at Ketambe, Nothern Sumatra, Indonesia. Int. J. Primatol. 16: 221-245.

van der Pijl, L. (1982). Principles of Dispersal in Higher Plants. Springer-Verlag, Berlin. van Roosmalen, M.G.M. (1985a). Fruits of the Guianan Flora. Institute of Systematic Botany Utrecht University and Silvicultural Department of Wageningen Agricultural University, Wageningen.

van Roosmalen, M.G.V. (1985b). Habitat preferences, diet, feeding strategy, and social organization of the black spider monkey (Ateles paniscus paniscus Linnaeus 1758) in Surinam. Acta Amazonica 15: 1-238.

van Schaik, C.P., Terborgh, J.W., and Wright, S.J. (1993). The phenology of tropical forests: adaptive significance and consequences for primary consumers. Ann. Rev. Ecol. Syst. 24: 353-377.

Wheelwright, N.T., and Orians, G.H. (1982). Seed dispersal by animals: contrasts with pollen dispersal, problems of terminology, and constraints on coevolution. Am. Nat. 119: 402-413. 